\title{
A Multidimensional Analysis of the Relationship between Corporate Social Responsibility and Firm's Financial Performance-Based on the Data of 78 Listed Companies in 10 years in Henan Province, China
}

\author{
Sida Chen*, Dongyong Zhang, Mengge Hao \\ College of Information and Management Sciences, Henan Agricultural University, Zhengzhou, China \\ Email: ^happycsd@hotmail.com
}

How to cite this paper: Chen, S., Zhang, D.Y. and Hao, M.G. (2019) A Multidimensional Analysis of the Relationship between Corporate Social Responsibility and Firm's Financial Performance-Based on the Data of 78 Listed Companies in 10 years in Henan Province, China. Open Journal of Applied Sciences, 9, 104-114.

https://doi.org/10.4236/ojapps.2019.93009

Received: December 14, 2018

Accepted: March 23, 2019

Published: March 26, 2019

Copyright $\odot 2019$ by author(s) and Scientific Research Publishing Inc. This work is licensed under the Creative Commons Attribution International License (CC BY 4.0).

http://creativecommons.org/licenses/by/4.0/

\begin{abstract}
At present, the research on the relationship of corporate social responsibility and economic performance mostly adopts the method of large-scale sampling, but does not distinguish the sample industries and regions, so the relevant research needs to be further analyzed. Based on the 2008-2017 data of 78 listed enterprises in Henan province, the relationship between corporate social responsibility and economic performance in 7 industries is measured by 8 indexes through Arellano-Bond dynamic panel data model. The research shows that the social responsibility of listed enterprises in Henan Province has a lagging impact on the economic performance of enterprises, which has a negative impact on the short-term and a positive impact on the long-term. The common point is that the responsibility of the investor has a positive impact on the economic performance of the enterprise, and other aspects vary greatly due to industry categories. In general, the degree of corporate social responsibility of listed enterprises in Henan Province is relatively low.
\end{abstract}

\section{Keywords}

Corporate Social Responsibility, Economic Performance, Arellano-Bond Dynamic Panel Data Model

\section{Introduction}

According to Carroll's "pyramid of CSR" $(1979,1991)$, corporate social respon- 
sibility (CSR) can be widely defined as "the social responsibility of business encompasses the economic, legal, ethical, and discretionary expectations that society has of organizations at a given point in time" [1]. With the development of economic globalization and market economy, corporate social responsibility has become a universal behavior of enterprises [2]. In order to prove the existence foundation and practical value of corporate social responsibility, a large number of scholars have devoted themselves to the empirical analysis of the relationship between corporate social responsibility and economic performance. However, the impact of corporate social responsibility on corporate economic performance is not always seen as positive, it is a complex process and affected by many factors. And there is no lack of objection, and the representative is the concept of maximizing shareholder profits proposed by Nobel Prize winner Friedman (1970). He believes that the survival of enterprises is only for the interests of shareholders [3], there is no need to bear other social responsibilities, and the contradiction of this view has prompted more scholars to devote themselves to relevant research.

In the context of China, corporate social responsibility was gradually introduced after the reform and opening-up in the last century. There are also many scholars studying the relationship between corporate social responsibility and corporate economic performance. The research of Li Zheng (2006) [4], Wen Subin and Fang Yuan (2008) [5] holds that the corporate social responsibility has a negative effect on the current financial performance, but in the long run, corporate social responsibility has a positive effect on its financial performance. Wang Huaiming and Song Tao (2007) [6] found that the responsibility of listed companies in China for the state, investors and public welfare undertakings is positively related to corporate performance, while the responsibility for employees is negatively correlated with corporate performance. Zhang Zhaoguo, Jin Xiaocui and Li Gengqin (2013) [7] show that the social responsibility of the lag period has a significant positive impact on the current financial performance, while the current financial performance has a significant positive impact on the current social responsibility. Based on the empirical study of large enterprises and medium and small-sized enterprises, Yang Yusu and Yang Shanlin (2016) [8] found that neither undertaking social responsibility will lead to the deterioration of short-term financial situation, but in the long run, the majority of large enterprises have a positive relationship, on the other hand, the medium and small-sized enterprises have more negative relationship, and both of them have negative correlation between employee and customer social responsibility and long-term financial performance. Therefore, the research on corporate social responsibility and corporate economic performance does not have a unified result due to the inconsistency of relevant definitions and measurement methods [9]. There may be short-term negative relationships between the two, but positive long-term relationships will dominate [10].

Through the above relevant literature, it is found that although the corporate social responsibility is measured, the industry or region in which the enterprise 
is located is not considered. According to the concept of corporate social responsibility itself, it refers to a number of measures and activities carried out by enterprises to improve the relationship with relevant stakeholders, and this is partly influenced by the industry or region in which the company is located [9] [11] [12]. Some scholars have studied corporate social responsibility in specific industries, such as the communications industry (Tian Hong (2009) [13]), the manufacturing industry (Wang Jianqiong et al. (2009) [14], Song Jianbo et al. (2009) [15]), financial banking industry (Qiao Haijun (2009) [16]) and food industry (Zhu Jinwei et al. (2012) [17]), etc. However, these studies did not compare results across multiple industries.

At the same time, in view of the fact that the possibility of corporate social responsibility behavior occurs in a non-linear manner over time, the purpose of this paper is to study the relationship between corporate social responsibility and corporate economic performance through Arellano-Bond dynamic panel data model in a multi-dimensional manner in combination with the industry in which the company is located based on the data of 78 listed companies in Henan Province in China from 2008 to 2017.

\section{Data and Methodology}

\subsection{Variables}

According to stakeholder theory, Freeman (1984) argues that stakeholders are all individuals and groups that can influence the achievement of an organization's goals or be influenced by an organization's achievement of its target processes [11]. Clarkson (1995) believes that "stakeholders refer to individuals or groups that have made certain specific investments in the enterprise and have assumed certain risks, and their activities can affect the achievement of the corporate objectives or be affected by the company's process of achieving its goals [12]. Compared to Freeman's point of view, this concept emphasizes specific investment and confirms the relevance of stakeholders to the firm. It believes that stakeholder theory provides a framework for more effective analysis of corporate social responsibility. Therefore, stakeholder theory determines the object and content of corporate social responsibility, provides a theoretical basis for empirical research on corporate social responsibility, and provides practical support for corporate social responsibility in empirical testing and it has become an important way for scholars to study corporate social responsibility [2].

At present, mature corporate social responsibility evaluation methods include reputation index method, content analysis method and KLD index method. However, due to the lack of perfect environment and system in China, there is no unified and authoritative social responsibility evaluation system. Combined with the experience of Chinese scholars Wen Subin [5], Wang Huaiming [6], Zhang Zhaoguo [7] and Yang Yusu [8], the variables set up in this paper are shown in Table 1. 
Table 1. The definition of variables.

\begin{tabular}{|c|c|c|c|c|}
\hline \multicolumn{2}{|c|}{ Variable Type } & Variable Name & Variable Code & Variable Description \\
\hline Explained variable & Economic performance & Weighted return on equity & ROE & \\
\hline \multirow{6}{*}{$\begin{array}{l}\text { Explanatory } \\
\text { variables }\end{array}$} & Responsibility to investors & Adjusted earnings per share & INVCSR & \\
\hline & Responsibility to employees & Employee income ratio & EMPCSR & $\begin{array}{l}\text { Employee benefits payable/main } \\
\text { business income }\end{array}$ \\
\hline & Responsibility to consumers & $\begin{array}{l}\text { Whether it passed ISO9000 } \\
\text { certification }\end{array}$ & CONCSR & Passed as 1 , failed to pass 0 \\
\hline & Responsibility to suppliers & Quick ratio & SUPCSR & $\begin{array}{l}\text { Quick ratio, which can better represent the } \\
\text { short-term solvency of enterprises }\end{array}$ \\
\hline & $\begin{array}{l}\text { Responsibility to the } \\
\text { government }\end{array}$ & tax rate & GOVCSR & Taxes payable/main business income \\
\hline & $\begin{array}{l}\text { Responsibility to the } \\
\text { environment }\end{array}$ & $\begin{array}{l}\text { Whether it passed ISO14000 } \\
\text { certification }\end{array}$ & ENVCSR & Passed as 1 , failed to pass 0 \\
\hline \multirow{2}{*}{ Control variables } & & Enterprise size logarithm & SIZE & $\begin{array}{l}\text { Natural logarithm of assets at the } \\
\text { end of the period }\end{array}$ \\
\hline & & Nature of business & OWNER & $\begin{array}{l}\text { State-owned enterprises are } 1, \\
\text { private enterprises are } 0\end{array}$ \\
\hline
\end{tabular}

Tips: Collected by the author.

\subsection{Data}

Henan Province is located in central China, with GDP ranking 5th (2017) in 34 provincial administrative regions, and its population accounts for $16.60 \%$ of the country's total population (2016). Therefore, the performance of its corporate social responsibility will have a wide impact. This article is based on the list of listed companies in Henan Province (April 30, 2018) by China Securities Regulatory Commission Henan Supervision Bureau, with 78 listed companies as relevant data for 2008-2017. All relevant data is obtained through websites such as Sina Finance and Tonghuashun Finance which provide authoritative and accessible financial information in China and corporate annual report. In detail, ROE, INVCSR, SUPCSR, SIZE and OWNER are obtained from Sina Finance and Tonghuashun Financial. EMPCSR and GOVCSR are obtained according to the annual report of the company. CONCSR and ENVCSR are obtained from the website of Certification and Accreditation Administration of the People's Republic of China. And data are screened by: 1) Excluding st, *st companies; 2) Exclude companies with missing data. Finally, the data of 63 listed companies were selected, and their industry distribution is shown in Table 2.

\subsection{Arellano-Bond Dynamic Panel Data Model}

Considering that there is a dynamic process between corporate social responsibility and corporate economic performance, economic performance indicators depend at least in part on their own values in the previous period. If traditional panel model estimation methods or OLS estimates are used, it will be difficult to obtain unbiased and consistent estimates. As a result, the hysteresis dependent variable is added to the model and the model is built as follows:

$$
\begin{aligned}
& R O E_{i t}=\beta_{0}+\sum_{j=1}^{M} \alpha_{j} R O E_{i, t-j}+\beta_{1} I N V C S R_{i t}+\beta_{2} E M P C S R_{i t}
\end{aligned}
$$

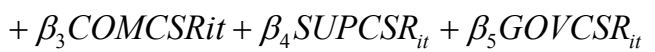

$$
\begin{aligned}
& +\beta_{6} E_{N V C S R_{i t}}+\beta_{7} \operatorname{SIZE}_{i t}+\beta_{8} O W N E R_{i t}+\varepsilon_{i t}
\end{aligned}
$$


Table 2. Enterprises industry distribution.

\begin{tabular}{|c|c|c|c|c|c|}
\hline Industry & Number & Proportion & Industry & Number & Proportion \\
\hline Manufacturing & 49 & $77.78 \%$ & Mining industry & 4 & $6.35 \%$ \\
\hline Information technology industry & 2 & $3.17 \%$ & Agriculture, forestry, animal husbandry and fishery & 2 & $3.17 \%$ \\
\hline Wholesale and retail trade & 1 & $1.59 \%$ & Total & 63 & $100.00 \%$ \\
\hline
\end{tabular}

Tips: According to the China securities regulatory commission's "second quarter 2018 listed companies industry classification results".

where, $R O E_{i, t-j}$ is the economic performance of the $i$ th enterprise lag $j$ period.

Because the regression equation explains the variable to contain the lag dependent variable, thus causes the independent variable to be related to the error term, that is, the independent variable of the model has the endogenous nature. Therefore, if the panel data is estimated with standard random effect or fixed effect, the parameter estimation will be biased and inconsistent. The differential GMM estimation proposed by Arellano and Bond (1991) [18] can solve this problem better. So Arellano-Bond dynamic panel data model is adopted.

\section{Results}

\subsection{Correlation Analysis}

The results of correlation analysis of all variables are given in Table 3 by Eviews 10 software.

From the correlation analysis in Table 3, ROE is significantly correlated with INVCSR, EMPCSR, SUPCSR, SIZE and OWNER. ROE is significantly positively correlated with INVCSR and CONCSR that the correlation coefficients are 0.6495 and 0.0373 , and ROE is significantly negative correlated with EMPCSR, SIZE and OWNER that the correlation coefficients are $-0.1600,-0.1078$ and -0.1184 . The significance between ROE and CONCSR, GOVCSR, ENVCSR is not obvious, but it is not certain that they are not related. To a certain extent, this shows the complex relationship between corporate social responsibility and corporate economic performance. At the same time, it can be seen that the listed companies in Henan province have better social responsibility to investors and worse social responsibility to employees. Compared with the average annual wage of urban non-private units and urban private units and the national average wage in 2017, the former is lower than the latter, to some extent, which is consistent with the results of the data to some extent.

It is worth noting that there is a significant negative correlation between ROE and SIZE, and generally there should be a positive relationship between enterprise size and corporate social responsibility, that is, the larger the size of the enterprise, the more it will assume social responsibility or implement responsibility strategy. The opposite result may be due to the fact that the listed enterprises in Henan Province do not attach great importance to corporate social responsibility 
Table 3. Variable correlation analysis.

\begin{tabular}{|c|c|c|c|c|c|c|c|c|c|}
\hline & ROE & INVCSR & EMPCSR & CONCSR & SUPCSR & GOVCSR & ENVCSR & SIZE & OWNER \\
\hline ROE & 1 & & & & & & & & \\
\hline INVCSR & $0.6495^{* * *}$ & 1 & & & & & & & \\
\hline EMPCSR & $-0.1600^{\star * *}$ & $-0.1042^{\star * *}$ & 1 & & & & & & \\
\hline CONCSR & 0.0373 & $0.0861^{* *}$ & -0.0653 & 1 & & & & & \\
\hline SUPCSR & $0.1017^{\star \star}$ & $0.1642^{\star * \star}$ & -0.0580 & $0.1679^{* * *}$ & 1 & & & & \\
\hline GOVCSR & -0.0160 & --0.0322 & $0.7722^{* * *}$ & $-0.0734^{*}$ & -0.0099 & 1 & & & \\
\hline ENVCSR & 0.0458 & $0.0673^{*}$ & $-0.1331^{\star * *}$ & $0.6508^{* * *}$ & $0.1836^{* * *}$ & $-0.0742^{*}$ & 1 & & \\
\hline SIZE & $-0.1078^{\star * *}$ & -0.0100 & $-0.0784^{\star \star}$ & $-0.1034^{\star * *}$ & $-0.2442^{\star * *}$ & $-0.1134^{\star * *}$ & -0.0503 & 1 & \\
\hline OWNER & $-0.1184^{\star * *}$ & $-0.1923^{\star * *}$ & -0.0522 & $-0.4212^{\star * *}$ & $-0.2058^{\star * *}$ & -0.0361 & $-0.2738^{\star * \star}$ & $0.3561^{\star * *}$ & 1 \\
\hline Min & -1.6539 & -2.4239 & $2.06 \mathrm{E}-05$ & 0.0000 & 0.1485 & -0.1162 & 0.0000 & 18.3102 & 0.0000 \\
\hline Max & 0.7574 & 4.4900 & 0.6733 & 1.0000 & 27.6730 & 30.1533 & 1.0000 & 25.3066 & 1.0000 \\
\hline Mean & 0.0757 & 0.3524 & 0.0176 & 0.6508 & 1.7218 & 0.0753 & 0.6508 & 21.9095 & 0.2857 \\
\hline Std. & 0.1981 & 0.5371 & 0.0327 & 0.4771 & 2.3678 & 1.2419 & 0.4771 & 1.2801 & 0.4521 \\
\hline Numbers & 630 & 630 & 630 & 630 & 630 & 630 & 630 & 630 & 630 \\
\hline
\end{tabular}

Tips: ${ }^{* * *},{ }^{* *}$ and ${ }^{*}$ are significant at the level of $1 \%, 5 \%$, and $10 \%$, respectively.

and neglect to undertake and construct related responsibilities. In addition, it is found that most of the variables with significant relationship are negatively related, which may be due to the fact that most of the listed companies in Henan Province are still in the stage of pursuing economic benefits. The construction of corporate social responsibility has not been promoted to the strategic level, and to a certain extent, corporate social responsibility cannot bring good economic feedback to enterprises. Judging from the result of standard deviation, the fluctuation degree of SUPCSR, GOVCSR and SIZE data is large, which reflects that the level of responsibility for some stakeholders varies greatly between enterprises because of the different economies of scale. The supplier is the most vulnerable party.

\subsection{Result Analysis}

According to the industry distribution table of Table 2, due to the small number of enterprises in other industries except manufacturing industry, the Arellano-Bond dynamic panel data model cannot be tested, so this paper first analyzes the Arellano-Bond dynamic panel of 63 companies in total, and then analyzes various industries through stepwise regression equations. Table 4 shows the data analysis results of the overall 63 listed companies obtained through the Arellano-Bond dynamic panel data model.

In Table 4, the social responsibility of listed enterprises in Henan Province has a negative impact on short-term economic performance, while in the long run, it has a positive impact, but the relationship is not obvious. The responsibility 
Table 4. Arellano-Bond dynamic panel data model global analysis.

\begin{tabular}{|c|c|c|c|c|}
\hline Variables & Lag period & Lag two & Lag three & Lag five \\
\hline Lag period & $-* * *$ & $-* * *$ & $-* * *$ & $-* * *$ \\
\hline Lag two & & $+* * *$ & $-* * *$ & $t^{* * *}$ \\
\hline Lag three & & & $-* * *$ & $-* * *$ \\
\hline Lag five & & & & $+^{* *}$ \\
\hline Lag five & & & & $-* * *$ \\
\hline INVCSR & $+* * *$ & $+* * *$ & $+* * *$ & $+* * *$ \\
\hline EMPCSR & $-* * *$ & $-* * *$ & $-* * *$ & $-* * *$ \\
\hline \multicolumn{5}{|l|}{ CONCSR } \\
\hline SUPCSR & $-* * *$ & $-* * *$ & $+^{* *}$ & + \\
\hline GOVCSR & $-* * *$ & $-* *$ & $-* * *$ & + \\
\hline \multicolumn{5}{|l|}{ ENVCSR } \\
\hline SIZE & + & + & $+^{* * *}$ & $+^{*}$ \\
\hline \multicolumn{5}{|l|}{ OWNER } \\
\hline Sargan-p & 0.1907 & 0.1677 & 0.2464 & 0.2000 \\
\hline $\mathrm{AR}(2)-\mathrm{p}$ & 0.3306 & 0.8115 & 0.9023 & 0.4798 \\
\hline
\end{tabular}

Tips: 1$)^{* * *},{ }^{* *}$ and ${ }^{*}$ are significant at the level of $1 \%, 5 \%$, and $10 \%$, respectively. 2$)+$ means that the variable has a positive impact on the economic performance of the company, - the opposite.

of enterprises to investors has always had a positive impact on the economic performance of enterprises. When investors export funds to support the development of enterprises, enterprises naturally bear the responsibility to investors. However, it is more likely that the listed companies in Henan Province pay too much attention to the investor side among the stakeholders, take economic interests as the primary goal, and ignore other stakeholders. On the other hand, Henan Province is located in the central part of China, with convenient transportation, and GDP ranks fifth in the country in 2017. However, per capita GDP and per capita income are both ranked 20, while Henan Province is shouldering the heavy responsibility of national granaries. To some extent, it can explain the pursuit of economic benefits of listed companies in Henan Province, which leads to neglect of other stakeholders.

On the contrary, the company undertakes responsibility to its employees has always had a negative impact on its economic performance. Generally speaking, the enterprise can only assume the responsibility to the employees, can improve the loyalty of the employees to the enterprise, which is conducive to giving full play to the combat effectiveness of the employees. In the study of Turban and Greening (1997) [19], it is found that socially responsible enterprises are more attractive to employees than those that are not socially responsible. Combined with the fact that the average wage level of Henan Province in 2017 is below the national average wage level, it is likely that the talent attraction of Henan Province will be weaker than that of the surrounding and coastal provinces, resulting in a decline in talent competitiveness. At the same time, the lower wage level will 
also affect the combat effectiveness of employees, which shows that the responsibility of the enterprise to employees has a negative impact on financial performance, and then create a vicious circle, which will be unfavorable to the future development of the enterprise.

The responsibility of enterprises to suppliers and the government has a short-term negative impact on the economic performance of enterprises. The possible reason is that enterprises have the probability of defaulting on funds and taxes, affecting cooperation between enterprises or government trust, which in turn affects the economic performance of enterprises. The analysis of the size of the enterprise may indicate that the enterprise will decide whether to assume social responsibility in the later stage according to the current economic situation, and the larger the enterprise, the more likely it is to assume social responsibility.

The results of each industry analysis are shown in Table 5 .

According to the results of Table 5, we can see that the influence of corporate social responsibility on corporate economic performance varies from industry to industry. Among the eight indicators listed, there are six significant correlations between corporate social responsibility and corporate economic performance in manufacturing, while there is only one significant correlation between hydropower and gas industry and transportation warehousing postal industry. The result may be that the latter's corporate nature is based on data showing that are all state-owned enterprises, and the services it provides are mostly people's basic living needs and less dependent on other stakeholders. Therefore, the latter is less relevant to other stakeholders; and the former is more susceptible to other stakeholders in the production and operation process, just like the wholesale and retail trade and agriculture, forestry, animal husbandry and fishery, so the former has a higher correlation with other stakeholders.

On the whole, the common point is that the responsibility of the company to the investor has a positive impact on the economic performance of the company. In terms of taking responsibility for employees, the manufacturing, agriculture, forestry, animal husbandry and fishery and mining industries show that the responsibility for employees has a negative impact on the economic performance of the company. The wholesale and retail trade shows the opposite, which may be due to the higher human resource costs of the former. In terms of taking responsibility for suppliers, the manufacturing, information technology industry, and wholesale and retail trade all show that the responsibility of the supplier has a negative impact on the economic performance of the company. In terms of taking responsibility for the government, manufacturing and agriculture, forestry, animal husbandry and fishery show that the responsibility for the government has a positive impact on the economic performance of the enterprise, while the wholesale and retail trade shows the opposite. In terms of the size of the enterprise, the manufacturing industry shows that the larger the enterprise, the more social responsibility will be taken, while the agriculture, forestry, animal 
Table 5. Regression analysis of seven industries.

\begin{tabular}{|c|c|c|c|c|c|c|c|}
\hline ROE & Manufacturing & $\begin{array}{l}\text { Mining } \\
\text { industry }\end{array}$ & $\begin{array}{l}\text { Hydropower and } \\
\text { gas industry }\end{array}$ & $\begin{array}{c}\text { Transportation } \\
\text { warehousing postal } \\
\text { industry }\end{array}$ & $\begin{array}{l}\text { Information } \\
\text { technology } \\
\text { industry }\end{array}$ & $\begin{array}{c}\text { Agriculture, } \\
\text { forestry, animal } \\
\text { husbandry and } \\
\text { fishery }\end{array}$ & $\begin{array}{l}\text { Wholesale and } \\
\text { retail trade }\end{array}$ \\
\hline INVCSR & $+* * *$ & $+* * *$ & $+* * *$ & $+* * *$ & $+* * *$ & $+^{* * *}$ & $+^{* * *}$ \\
\hline EMPCSR & $-* * *$ & $-^{*}$ & & & & $-^{*}$ & $+^{*}$ \\
\hline \multicolumn{8}{|l|}{ CONCSR } \\
\hline SUPCSR & $-* *$ & & & & $-* *$ & & $-* *$ \\
\hline GOVCSR & $+* *$ & & & & & $t^{* *}$ & $-* *$ \\
\hline \multicolumn{8}{|l|}{ ENVCSR } \\
\hline SIZE & $+* * *$ & & & & & $-* * *$ & $-*$ \\
\hline OWNER & $+^{* *}$ & $-* * *$ & & & & & \\
\hline $\operatorname{Sum}(+)$ & 4 & 2 & 1 & 1 & 2 & 2 & 2 \\
\hline Sum $(-)$ & 2 & & & & & 2 & 3 \\
\hline Total & 6 & 2 & 1 & 1 & 2 & 4 & 5 \\
\hline
\end{tabular}

Tips: 1$)^{* * *}{ }^{* *}$ and ${ }^{*}$ are significant at the level of $1 \%, 5 \%$, and $10 \%$, respectively. 2$)+$ means that the variable has a positive impact on the economic performance of the company, - the opposite.

husbandry, fishery and wholesale and retail trade show the opposite. In terms of the nature of the enterprise, the manufacturing industry is willing to assume social responsibility when it is a state-owned enterprise, while the mining industry shows the opposite.

\section{Conclusions}

Based on the indicators of investors, employees, consumers, suppliers, government, environment, enterprise scale and enterprise nature, this paper studies the relationship of corporate social responsibility and corporate economy performance in various industries based on data from 78 listed companies in Henan Province for 10 years. By constructing the Arellano-Bond dynamic panel data model, it is found that the social responsibility of listed enterprises in Henan Province has a lag to the economic performance of enterprises, but this lag is not obvious. The obvious commonality in various industries is that the responsibility of the company to bear the investor has a positive impact on the economic performance of the enterprise. In other respects, the industry differences are quite different. For example, in terms of responsibilities to employees, according to Table 5, the responsibility of the wholesale and retail industry for employees has a positive impact on economic performance, while the manufacturing, mining and agriculture, forestry, animal husbandry and fisheries have a negative impact, and there are quite a few differences in other indicators.

Therefore, it is necessary to conduct a detailed and in-depth study of the relationship between corporate social responsibility and economic performance among industries according to each industry, nature, scale and other variables. 
In general, the corporate social responsibility of listed enterprises in Henan Province is weak, and the economic performance is the primary goal of development. In addition, there are also shortcomings in this paper, such as small sample size, single regional selection failure to conduct regional comparison analysis, which will be improved in future research.

\section{Conflicts of Interest}

The authors declare no conflicts of interest regarding the publication of this paper.

\section{References}

[1] Carroll, A.B. (2008) A History of Corporate Social Responsibility: Concepts and Practices. In: Crane, A., Matten, D., McWilliams, A., Moon, J. and Siegel, D.S., Eds., The Oxford Handbook of Corporate Social Responsibility, Oxford University Press, Oxford.

[2] Carroll, A.B. (2015) Corporate Social Responsibility: The Centerpiece of Competing and Complementary Frameworks. Organizational Dynamics, 44, 87-96. https://doi.org/10.1016/j.orgdyn.2015.02.002

[3] Friedman, M. (1970) The Social Responsibility of Business Is to Increase Its Profits. New York Times Magazine, No. 9, 122-126.

[4] Li, Z. (2006) Research on the Correlation between Corporate Social Responsibility and Corporate Value-Evidence from Shanghai Listed Companies. China Industrial Economy, No. 2, 77-83.

[5] Wen, S.B. and Fang, Y. (2008) An Empirical Study on the Relationship between Corporate Social Responsibility and Financial Performance-A Panel Data Analysis from the Perspective of Stakeholders. China Industrial Economy, No. 10, 150-160.

[6] Wang, H.M. and Song, T. (2007) An Empirical Study of Social Responsibility and Corporate Performance of China's Listed Companies-Evidence from Shanghai Stock Exchange 180 Index. Journal of Nanjing Normal University (Social Science Edition), No. 2, 58-62.

[7] Zhang, Z.G., Yan, X.C. and Li, G.Q. (2013) An Empirical Study on the Inter-Temporal Impact of Corporate Social Responsibility and Financial Performance. Accounting Research, No. 8, 32-39.

[8] Yang, Y.S. and Yang, S.L. (2016) An Empirical Study of the Relationship between Corporate Social Responsibility and Financial Performance in China's Situation-Based on Comparative Analysis of Large, Medium and Small Listed Companies. Chinese Management Science, 24, 143-150.

[9] Blasi, S., Caporin, M. and Fontini, F. (2018) A Multidimensional Analysis of the Relationship between Corporate Social Responsibility and Firms' Economic Performance. Ecological Economics, 147, 218-229. https://doi.org/10.1016/j.ecolecon.2018.01.014

[10] Li, G.P. and Wei, X.W. (2014) The Connotation, Measurement and Economic Consequences of Corporate Social Responsibility-Based on the Research of Foreign Corporate Social Responsibility Theory. Accounting Research, No. 8, 33-40.

[11] Freeman, R.E. (1984) Strategic Management: A Stakeholder Approach. Pitman Press, Boston, MA.

[12] Clarkson, M.B.E. (1995) A Stakeholder Framework for Analyzing and Evaluating Corporate Social Performance. Academy of Management Review, 20, 92-117. 
https://doi.org/10.5465/amr.1995.9503271994

[13] Tian, H. (2009) Correlation between Corporate Social Responsibility and Corporate Performance-Based on Empirical Data of China's Communication Industry. Economic Management, No. 1, 72-79.

[14] Wang, J.Q. and He, J.Y. (2009) Corporate Governance, Corporate Economic Performance and Corporate Social Responsibility-An Empirical Study Based on Data of Chinese Manufacturing Listed Companies. Economic Survey, No. 2, 83-86.

[15] Song, J.B. and Sheng, C.Y. (2009) Research on the Evaluation of Corporate Social Responsibility Based on Stakeholders-Taking Listed Companies in Manufacturing Industry as an Example. China Soft Science, No. 10, 153-163.

[16] Qiao, H.Z. and Tan, M. (2009) An Empirical Study on the Relationship between Social Responsibility and Financial Performance of Financial Enterprises. Finance and Economics Theory and Practice, 30, 17-21.

[17] Zhu, J.W. and Li, B.X. (2012) Research on Influencing Factors of Social Responsibility Information Disclosure in Food Enterprises. Economics and Management Research, No. 5, 123-128.

[18] Arellano, M. and Bond, S. (1991) Some Tests of Specification for Panel Data: Monte Carlo Evidence and an Application to Employment Equations. The Review of Economic Studies, 58, 277-297.

[19] Turban, D.B. and Greening, D.W. (1997) Corporate Social Performance and Organizational Attractiveness to Prospective Employees. Academy of Management Journal, 40, 658-672. 